\title{
Low-Dose Rate Brachytherapy
}

National Cancer Institute

\section{Source}

National Cancer Institute. Low-Dose Rate Brachytherapy. NCI Thesaurus. Code C85254.

Internal radiation treatment that targets a cancerous tissue with low doses of radiation through the use of inserted temporary or permanent implants. 